\title{
Divan Şiirinde Arapçanın Anlamsal Değeri
}

\author{
Tahir ARAZ1
}

Atıf/C): Araz, Tahir, Divan Şiirinde Arapçanın Anlamsal Değeri, Artuklu İnsan ve Toplum Bilim Dergisi 2020/5 (1), 60-81.

Öz

Muhtelif kültürler arasında tekâmül eden ve "Divan Edebiyatı" olarak tanımlanan Osmanlı Edebiyatı, Türklerin İslam kültüründen etkilenmeleri sonucu oluşturdukları geniş yelpazeli bir edebiyat olup bazı kaynaklarda "Eski Türk Edebiyatı" ve "Klasik Türk Edebiyatı" şeklinde de geçmektedir. Ancak belli ilkeler çevresinde gelişen bu edebiyat, şairlerin şiirlerini "Divan" denilen yazma kitaplarda toplamalarından dolayı daha çok "Divan Edebiyatı" adıyla ifade edilmektedir. Güçlü kültürel bir alt yapıya sahip olan ve Arap ile Fars edebiyatı muhitinde gelişme göstermekle birlikte kendine has üslubunu oluştururken ihtiva ettiği kaynaklar bağlamında Divan edebiyatı Arapça ve Farş̧adan kelime almıştır. Arapça kelimelerin Divan şiirinde bazen anlam daralmasına veya kaymasına uğradığını bazen de anlam genişlemesiyle beyitlerde yer edindiğini yaptı̆̆ımız tahliller neticesinde gözlemleyerek söz konusu kelimelerin anlamsal değerini yansıtmaya çalıştık. Dilin asli uzuvları hâline gelen ve toplumun öz değerleriyle birleşip mükemmel bir harmanı oluşturan bu kelimeler, kökleri ve yapıları bakımından yabancı olmakla birlikte edebî ve fikri kültürün yansıtıcısı olmuştur. Bu çalışmada Divan şiirine muhtelif yollarla girip Türkçenin ruhuyla izdivaç eden Arapça kelimeler ve bu kelimelerin zaman içindeki anlamsal değeri farklı beyitler üzerinden izah edilip değerlendirilecektir.

Anahtar Kelimeler: Divan Şiiri, Arapça, Beyit.

\section{The Semantic Value of Arabic in Divan (Ottoman) Poetry}

Citation/(C): Araz, Tahir, The Semantic Value of Arabic in Divan (Ottomon) Poetry, Artuklu Human and Social Science Journal 2020/5 (1), 60-81.

\section{Abstract}

Ottoman Literature which has evolved among various cultures and is also known as "Old Turkish Literature", is a wide-ranging literature created by Turks influenced by Islamic culture, and it is also referred to as "Havas Literature" and "Classical Turkish Literature" in some sources. However, this literature, which was developed within the framework of certain principles, is mostly referred to as "Divan Literature" because of the fact that poets gathered their poems in writing books called "Divan". Divan literature, which has a strong cultural infrastructure was developed within the atmosphere of the Arabic and Persian literature so that in terms of the resources it contains, it has taken its words from Arabic and Persian while creating its own style. In this work, we tried to reflect the semantic value of these words by observing that the Arabic words were sometimes subjected to loss of meaning or shifting or sometimes extension of the meaning of words in the couplets in Divan poetry. These words, which have become the essential parts of the Divan literature language combined with the core values of the society and formed a perfect blend have been the reflection of the culture with its literacy and inspiration even though, in terms of their roots and structures, they are foreign. In this study, Arabic words have entered the Divan poetry in various ways and merged with the spirit of Turkish as well as the evolution of semantic value over time of these words will be assessed through different couplets.

Keywords: Divan Poetry, Arabic, Couplet.

${ }^{1}$ Yüksek Lisans Öğrencisi, Mardin Artuklu Üniversitesi, Türkiye'de Yaşayan Diller Enstitüsü, Arap Dili ve Kültürü Anabilim Dalı, tahiraraz@hotmail.com, ORCID: Orcid.org/0000-0002-0225-128X.

Geliş/Received: 19.04.2020, Kabul/Accepted: 05.07.2020 


\section{GİRiş}

Edebiyat, sürekli gelişen, değişen, oluştuğu toplumdan kopuk olmayan; hatta o toplumu tanıtan, toplumların asli ihtiyaçlarını karşıladıktan sonra uğraştıkları bir alan olmakla birlikte dış çevreden de etkilenen ve aynı zamanda canlı olan dilin sanatsal bir döngüsü şeklinde tanımlanabilir. Edebiyatın gelişim safhaları, farklı mekân ve zamanlarda değişik nitelikler göstermektedir. Arapların İslam öncesinde yaşadıkları dönem “el-Câhiliyye” ve “el-'Asru'lcâhilı̀" gibi adlarla adlandırılmış olmakla birlikte bu tesmiyenin medeni seviyenin belirlenmesiyle alakalı olmayıp, bundan maksat İslamiyet'ten önceki dönemin inanç buhranını yansıtmak olmuştur. İşte Arap edebiyatına ait bulguların da temeli cahiliye devri olarak bilinen bu çağlara dayandırılır. Şiirin adeta kutsandığı ve güzel söz söyleyenlerin saygı gördüğü söz konusu dönemde her yıl Ukaz başta olmak üzere, Dumetu'l-Cendel, Hecer, Suhar, Mecenne ve Zu'l-Mecaz gibi yerlerde yapılan ve festival şeklinde geçen yarışmalar meşhur olup dereceye giren şiirlerin Kâbe'nin duvarlarına asılması şiirin gelişip yaygınlaşmasına büyük katkı sağlarken, sosyal ilişkilerin de gelişmesine aracılık etmiştir. Ki bu şiirlere Araplarda "asılan” manasına gelen "mu ‘allakât”' denilmiştir. (Demirayak, 2014: 9).

Arap yarımadasında hayat bulan bu edebiyat, İslam dininin tebliğ edilmesiyle birlikte daha geniş bir alana yayılmış ve ulaştığı mıntıkalardaki edebiyatlardan da etkilenerek, İslami kimlikle birlikte gelişme göstermiştir. Bundan da anlaşılacağı gibi Arap edebiyatı, geniş bir coğrafyanın emeğinden oluşmuş renkli bir edebiyattır. Moğolların da batıya yönelmeleri ve Arap, Fars ile Türk mıntıkalarının bazı kesimlerini istila etmeleri klasik edebiyata farklı bir nitelik kazandırırken değişik konuların edebiyata girmesine sebep olmuştur. Toplumların edebî birikimlerinin tek bir kültür halkasında geliştikleri gözlenen bir durum değildir. Edebiyat kaynağını toplumun derinliklerinden alırken, çoğu zaman dış unsurlardan da etkilenerek kendine has nitelikleriyle var olur. Örneğin, Klasik Fars edebiyatında köklü yönetim unsurları hâkimken, Eski Arap edebiyatında aşk kavramı daha çok kullanılır. Bunda kısacası toplumun yapısı ve bulunduğu coğrafyanın etkisi ile yaşam koşulları ve düşünce yapısının etkili olduğu söylenebilir.

Türklerin miladi 751 tarihinde Müslüman Araplarla birlikte Çinlilere karşı giriştikleri Talas Savaşı'ndan sonra IX. ve X. asırlarda kitleler hâlinde İslam'a girmesiyle yeni bir kültür halkasına dâhil olduklarını görürüz. Bu halka Türklerin sosyal, siyasal alanda köklü bir şekilde değişmelerine vesile olmuş ve aynı durum fiili olarak yaşamlarına da yansımıştır. Özellikle Abbasiler devrinde farklı görevlere getirilip İslam'ın hizmetine giren Türkler, bu hizmeti icra ederken İslam kültür ve medeniyetinden bir hayli etkilenerek, örf ve adetleri ile İslam kültürünü bir potada birleştirmeye gayret etmişlerdir. (Levend, 2015a: 18-27).

X. asırla birlikte din adına cihat edip İslam diyarını genişleten Müslüman Türkler, bu asırdan itibaren siyasi alanda olduğu gibi edebiyat sahasında da kendilerini ciddi bir şekilde göstermişlerdir. Özellikle Anadolu'nun İslamlaşması sürecinde dini şahsiyetlerin etken role sahip olması edebiyatı da etkileyerek edebî zevk ve anlayışın dini bir çerçevede gelişme göstermesine vesile olmuştur. $\mathrm{Bu}$ açıdan söz konusu dönemin özellikle dini-didaktik eserleri, müelliflerin Kur'an, hadis, kıssalar, Peygamber Efendimizin sünnetinden ve sahabelerin hayatları ile önemli dini şahsiyetlerden etkilenmeleri sonucunda telif edildiği görülür.

Anadolu'nun tam manasıyla İslamlaştığı XIV. ve XV. yüzyıllarda Türk edebiyatının gelişmeye başladığını, İran İslami edebiyatından ve İran mitolojisinden etkilenmekle birlikte bu edebiyatın seviyesinde eserler vermeye başladığı görülür. Bununla birlikte Divan edebiyatı asıl hüviyetini XVI. yüzyılla birlikte tamamlar ve İran edebiyatı ile boy ölçüşebilecek bir düzeye erişir. Divan edebiyatının kaynaklarına bakıldığında Agâh Sırrı Levend'in ifadesiyle, "Kur'an ve hadis, kıssalar ve mucizeler, tarih ve esatir, batıl ve hakiki ilimler, bu kaynakların başında gelir." 
(Levend, 2015 b: 15). Dolayısıyla söz konusu kaynaklara bakarak Divan edebiyatının İslami bir daire içinde menşe bulduğunu ve bu daire içinde gelişme gösterdiğini ifade edebiliriz.

Uzun bir süreç içerisinde İslam dinine giren Türkler, bazen münferit bazen de toplu hâlde Hak yoluna ermiş ve bu yolda cihat etmişlerdir. İslamiyet'e girip bulundukları yerlerde farklı adlar altında devletler tesis ederek İslam dinine hizmet eden Türkler tarafından X. yüzyıl ile birlikte kurulan devletlerin çoğunda avam dili Türkçe iken resmi dilin Arapça veya Farsça olduğu görülür. $\mathrm{Bu}$ durum toplumun geniş bir kısmına yansırken birçok ibare ve mefhumun Arapça ve Farsça olarak kullanılmasına sebep olmuştur. Kültür birikimi bu şekilde gelişen Türklerin özellikle Selçuklular döneminde Farsçaya biraz daha ağırlık verdiği gözlerden kaçmaz. Bunun sebebi olarak Selçuklu devletinin, derin bir kültür birikimine sahip olan Fars toplumunda hüküm sürüp bu topraklarda kurulmuş olması gösterilebilir. Selçuklu hanedanı Fars edebiyatına olan hayranlıklarını gizleme gereği duymayarak Fars edebiyatı şairlerini takdir etmişlerdir. (Mengi, 2010: 19).

Moğolların barbar bir şekilde batıya yönelmeleri Selçukluların yavaş yavaş çökmesine sebep olurken, bazı Türk aşiretlerin de Anadolu'ya göç etmesine sebep olup yeni yerleşim alanlarının şekillenmesine temel oluşturmuştur. Kurulan beylikler ve buna müteakip olarak XIII. yüzyılda Osmanlı Devleti'nin filizlenmesi yeni bir kültür sahasının meydana gelmesine vesile olmuştur. Selçukluların ardından Osmanlı Devleti'nde de edebî dil olarak Farsça kullanılırken ilmi eserlerde Arapça tercih edilmiştir. Buna rağmen Fars edebiyatının hayal dünyasından yararlanan divan şairleri, kelime muhtevası açısından eserlerinde Arapçadan azami derecede istifade etmiş ve bu edebiyatın genel olarak edebî kavramlarını kullanarak, yeni bir edebî oluşuma zemin hazırlamışlardır. Öyle ki; umumi bir bakıș açısıyla Divan edebiyatı nazım şekilleri, edebî sanatlar ve edebî türlerin hemen hemen tüm kavramlarının Arap edebiyatından istinsah edildiğini ifade edebiliriz. Bununla birlikte edebî sanatlar Türk edebiyatının ruhuna uygun kendine has, özgün bir şekilde kullanılmıştır. Buna ilaveten Divan şiirine damgasını vuran aruz ölçüsünün de bu edebî muhitten Divan edebiyatına intikal ettiğini belirtmek yerinde olacaktır. Şiirde Arapça ve Farsça kelimelerin geniş ölçüde kullanılmasını etkileyen bir diğer etken de aruz kalıbı bahirlerinin şiire uygulanmasidir.

Geniş bir kültür ağından beslenen Divan edebiyatına Arapça kelimeler, muhtelif yollardan girmiş ve bazen anlam daralmasına uğrarken bazen de anlam genişlemesiyle karşımıza çıkmış veya anlamını olduğu gibi korumuştur. Arapça kelimeler; dini mefhumlar, atasözleri, hikmetli sözler, deyimler ve kalıplaşmış ifadeler şeklinde Divan şiirine girerek bu şiirde adeta etle kemik gibi yoğrulmuş ve şiirin ana unsuru hâline gelmiştir. Arapça kelimelerin bir kısmı doğrudan bu dille temas sonucu Divan şiirine girerken bir kısmı da Fars edebiyatı süzgecinden geçerek kalıp hâlinde Türk şiirine geçiş yapmıştır. Dini inanç, zamanla birlikte ortak kültürel öğelerin oluşumu, Arapçanın müzikal derinliği ve Divan şiirine aruz kalıbının uydurulabilmesi adına Arapçadan birçok kelime kamus ve tabi-i yollarla Türkçeye geçerek bu dile renk katmıştır. (Doğan, 2013: 1132). Bununla birlikte “medh" kültürü aracılığıyla da Peygamberimiz ve bazı sahabeler için kullanılan kalıp ifadeler, oldukları gibi Divan şiirine geçmiştir.

Divan edebiyatının asli kaynaklarından biri olan Kur'an-1 Kerim'de kendilerine telmihte bulunulan sahabelerin edebiyatta yer almamaları düşünülemez. "Başlarına gelenlerden sonra yine Allah'ın ve resulün çağrısına uyarlar. Bunların içinden iyilik yapanlar ve takva sahibi olanlar için pek büyük bir mükâfat vardır" (Ali İmran, 2/172) mealindeki ayet ve daha birçok ayette kendilerinden ad belirtmeksizin bahsedilen sahabeler, divan edebiyatında ilim ve irfanlarıyla, sadık oluşlarıyla, hizmetleriyle, yiğitlikleriyle, Peygamberimize yakınlık dereceleriyle ve dönemin hadiseleri ile olan bağlantılarına binaen şiire konu olmuşlardır. İşte bu vesileyle Arap edebiyatında sahabeler için kullanılan sıfatların çoğu aslını koruyarak Divan şiirine girip kalıplaşmıştır. 
Divan edebiyatında şairlerin divanlarında tevhid, münacaat, naat, medh-i çâr yâr, fahriye gibi nazım türlerinde ve Efendimizi anlatan eserlerde bazen müstakil başlıklar altında bazen de divanların farklı beyitlerinde sahabelerin adı geçmektedir. Özellikle dört halifenin, Peygamber Efendimize istinat edilen hadisler çerçevesinde vasıflandırıldıkları ve iktibas sanatıyla birçok ayet ve hadisin bu şiirde kullanılması da Arapça kelimelerin mısralarda geniş bir yer kaplamasına zemin hazırlamıştır.

Ünlü Türk şairlerinden olan Ali Şir Nevâ-i (ö.1501) "Muhâkemetü'l-Luğateyn" adlı eserinde Türkçenin Farsçadan üstün olduğunu yansıtmaya çalışırken, Arapça ile aynı anlatım gücüne sahip olduğunu ifade etmiştir. Eserinin adı başta olmak üzere çoğunda Arapça kelimelerin mevcudiyeti bu dil ile olan münasebetin gücünü yansıtmaktadır. Öyle ki, Kaşgarlı Mahmud'un Dîvân-ü Lügati’t-Türk adlı sözlük mahiyetindeki eserin adı dahi Arapça kelimelerden oluşmakta olup bu eser Abbasi halifesi el-Muktedi bi-Emrillah'ın oğlu Ebu'l Kasım Abdullah'a miladi 1077 tarihinde sunulmuştur. (Kemikli, 2015: 48). Aşağıda Divan edebiyatının kaynaklarına göz attığımızda, Arapça kelimelerin Divan şiirinde kapladığı yerin ve dilin ayrılmaz bir parçası oluşunun sebebine kapı aralamış olacağız.

\section{Divan Edebiyatının Ana Kaynakları}

Divan edebiyatının ana kaynaklarına bakıldığında Agâh Sırrı Levend'in ifadesiyle, "Kur'an ve hadis, kissalar ve mucizeler, tarih ve esatir, batıl ve hakiki ilimler, bu kaynakların başlnda gelir." (Levend, 2015 b: 15). Dolayısıyla bu bağlamda Divan edebiyatının İslami bir daire içinde menşe bulup bu daire içinde gelişme gösterdiğini söz konusu ifadeden anlamaktayı. Ana kaynaklara baktığımızda Arapça kelimelerin Divan şiirinde hangi boyutlarda yer kapladığını tahmin etmekte zorlanmayacağız. Fransız şair, yazar ve düşünür Paul Valery, "Aslanın vücudu yediği hayvanlardan oluşur," (Kaplan, 2006: 163) sözüyle birikimin ve meydana gelen sentezin unsurlarına değinirken tam da Divan edebiyatı oluşumuna benzer bir noktaya atıfta bulunmuştur. Divan şiirine genel olarak göz attığımızda da gerçekte bu sözün fiili hâlini görürüz ki, Divan şiiri farklılıkları da içinde eriterek yeni bir bileşimle büyük bir mozaiği oluşturmuştur. Aşağıda bu mozaiğin ana kaynaklarını kısaca sıraladık.

Kur'an ayetleri ve hadisler, kıssalar ve efendimizin hayatı.

Tefsir, kelam, hadis, fikıh gibi dini bilgilerin yoğun olduğu dallar.

Meşhur tarihi olaylar. Gazavatnameler, fetihnameler vs.

Tasavvufun etkisi, şairlerin mutasavvıfların etkisinde kalması.

Mitoloji, özellikle Firdevsi'nin Şehname adlı eserinin etkisi.

Büyük evliyaların kerametleriyle ilgili hikâyeler.

Tarihi efsanevi olaylar, esatir denilen hayal-gerçek karışımı anlatılar.

Kimya, simya, hikmet, felsefe, tıp, astronomi, musiki, beşerî ilimler.

Anadolu insanının gelenek ve görenekleri,

Atasözleri, (Arapça, Farsça, Türkçe) deyimler, hikmetli sözler.

\section{Arapça Kelimelerin Divan Şiirindeki Yeri}

\section{Peygamber Efendimizin Medhi İçin Kullanılanlar}

Divan edebiyatıyla ilgili girişten sonra, Arapça kelimelerin Divan şiirindeki yerine beyitler üzerinden göz atmak yerinde olacaktır. Söz konusu çalışmamızda Divan şiirinin muhtelif dönemlerinden örnekler seçilerek teması farklı beyitler üzerinden konuya değinilecektir.

Fuzuli’nin Peygamber Efendimizi övdüğü ve ona olan hasretini yansıttığı meşhur "Su Kasidesi"nden (Gölpınarlı, 2006: 15-16) alınmış olan aşağıdaki beyitlerde kullanılan Arapça 
kelimelerin bazısı tek başına, bazısı da Farsça veya Türkçe kelime ve eklerle kalıp (tamlama) şeklinde kullanılmıştır.

\section{"Men lebün müştâkıyam zühhâd kevser talibi}

Nitekim meste mey içmek hoş gelür huşyâre su"

Ben dudağını arzuluyorum, sofular ise cennetteki kevsere talipler. Nitekim sarhoşa şarap içmek, aklı başında olana da su içmek hoş gelir. Beyitte müştak özleyen, zühhad sufi, kevser hayat suyu, talib isteyen, arzulayan; mey şarap manasında kullanılmıştır. Müştak kelimesi “am-em' Farsça kişi zamirinin eki ile çekimlenerek kullanılmıştır. Dolayısıyla Arapça bir kelime Farsça dilbilgisi öğesiyle birleştirilerek kullanılmıştır.

\section{"Hayret ilen barmağın dişler kim itse istimâ • Barmağından virdügi şiddet güni ensâre su”}

Sıkıntı günü Efendimizin ensara parmağından su verdiğini kim işitse hayret ile parmağını 1sırır. Beyitte hayret şaşılan şey, istima' işitmek, ensar Medineli Müslümanlar manasında kullanılmışken, şiddet asıl manasından sıyrılarak zor gün manasında kullanılmıştır. Ayrıca ensar kelimesinin sonuna Türkçe "a-e" yönelme hâl eki getirilerek kullanılmış ve Medineli Müslümanlara işaret edilmiştir.

\section{"Eylemiş her katreden min bahr-ı rahmet mevc-hîz \\ El sunup urgaç vuzîu' içün gül-i ruhsâre su”}

Abdest almak için gül yanaklarına el uzatıp yüzüne su vurunca sıçrayan her su damlasından binlerce rahmet denizi dalgalanmıştır. Beyitte katre damla, bahr-l rahmet rahmet denizi, mevc dalga, vuzu' abdest manasında kullanılmıştır. Bahr-l rahmet mevc Farsça tamlama üslubuyla birleştirilmiş, katre kelimesi de "den" ayrılma hâl ekiyle kullanılarak damlalardan manası hâsıl olmuştur. Aynı mısrada Arapçada ayrılma hâl eki olan "min” harfi cerin de kullanılmış olması dikkat çekicidir. Dolayısıyla farklı dillere ait dil bilgisi öğeleri aynı mısrada kullanılabilmiştir.

\section{"Yâ Habîballâh yâ Hayre'l-beşer müştâkunam}

Eyle kim leb-teşneler yanup diler hemvâre su”

Ey Allah'ın sevgilisi! Ey insanların en hayırlısı! Seni tıpkı susuzluktan dudağı kuruyanların sürekli su diledikleri gibi özlüyorum. Beyitte ' $y a$ ' seslenme edatı olarak ey, habîballâh Allah'ın sevgilisi, hayre'l-beşer insanlığın en hayırlısı, müştak özleyen manasında kullanılmıştır. Müştak kelimesi Farsça “men” zamirinin ekiyle tamamlanarak, ben özledim manasında beyitte yerini bulmuştur. Birinci mısradaki terkipsel kullanımın Arapça olması nadir olan durumlardandır.

\section{"Sensen ol bahr-ı keramet kim şeb-i mi'râcda \\ Şebnem-i feyzün yetürmüş sabit ü seyyâre su”}

Sen o keramet denizisin ki, feyzinin çiğ damlaları Miraç gecesinde sabit yıldızlara ve gezegenlere su yetiştirmiştir. Beyitte bahr-ı keramet Farsça terkiple cömertlik denizi, şeb-i mi 'râc mirac gecesi (Farsça gece kelimesiyle), feyz bereket manasında kullanılmıştır. Ayrıca Türkçe "ün” tamlanan ekiyle birlikte kullanılarak senin feyzin şeklinde sen kişi zamirine isnat edilmiştir. Sabit hareket etmeyen, seyyâre hareket hâlinde olup bu iki kelime ise asli manaları dışında gezegen ve yıldızlar manasında kullanılmıştır. 


\section{Peygamberimizi Öven Şair Sahabelere Telmihte Bulunma}

Muhtelif divanlardan alınan aşağıdaki beyitlerde de bazı sahabelerle aşere-i mübeşşerenin medhedildiğini ve bu medih vasıtasıyla Arapça kelimelerin Divan şiirine intikal ettiğini görürüz.

"Benem mümtaz-ı küll meddah-ı sultan-ı rüsül şimdi

Benem Hakka bu kim meydan-ı nazmun şimdi Hassânı” (Işınsu, 2002: 41).

Yukarıdaki beytinde Rızâyî (ö.1594) seçkin kişi olan peygamberler sultanının övücüsü olduğunu ifade edip, döneminin de şiir meydanında kendisini Hassan’a (ö.680) benzeterek Hz. Peygamber'in şairine göndermede bulunmuştur. Dolayısıyla hem teşbih hem de telmih sanatının kullanıldığı görülür. Ubeydi, Neşati, Nefi başta olmak üzere Divan şiirinde bu tarz beyitlere rastlamak mümkündür. Bahsi geçen beyitlerde şairler genellikle kendilerini, Efendimizin şairi Hassan'la kıyaslamış olup, bazı beyitlerde de Hassan'ı övmüş onun yolunu takip ettiklerini belirterek bununla iftihar etmişlerdir. Kelime tahliline baktığımızda mümtaz en iyi, küll hepsi, meddah övücü, sultan en büyük, rüsül peygamberler, Hakka hem Allah hem de gerçekten manasında, meydan saha, alan, nazm şiir manasında kullanılmıştır. Fakat kelimelerin çoğu Farsça terkipler vasıtasıyla yan yana getirilerek kullanılmış ve bu sayede şiirde musiki oluşturulmuştur.

\section{Sahabelerin Medhi İçin Kullanılanlar}

Divan edebiyatında Hz. Muhammed (s.a.v.) vefatından sonra dini ayakta tutan ve Efendimize yakınlığıyla bilinen Hz. Ebubekir, sıddîk, atik, yar-ı gar, makbul-i Huda gibi vasıflarla geçmektedir. Bunlardan "sıddîk" olanı önemli bir yer kaplamaktadır. "Atik" olanı ise Efendimizden rivayet edilen "Sen Allah'ın cehennemden azad ettiği kimsesin." (Tirmizî, Menâkıb:16) hadisine binaen Divan şiirinde geçmektedir.

"Gördüğü zaman inanan Ebâ Bekr-i Siddîk'dır

Üstün olub dayanan Ebâ Bekr-i Siddîk'dır” (Aksu, 2009: 281).

Hazreti Ebubekir'e gelen müşrikler inanılması güç gibi görünen Miraç hadisesini anlattıklarında bunları Muhammed mi söyledi der, müşrikler evet derler. Bunun üzerine Hazreti Ebubekir o şöylemişse doğru söylemiştir diyerek müşriklerin oyununa gelmemiştir. Beyitte sıddîk kelimesi doğru olan, sadık olan manasında kullanılmıştır. Zaman kelimesi de Arapça olup bilinen vakit-o an manasında kullanılmıştır. Ebâ baba, Ebâ Bekr ise Bekir'in babası şeklinde yerini bulmuştur.

Dört halifeden ikincisi olan ve adaletiyle meşhur Hazreti Ömer'in de divan edebiyatında önemli bir yere sahip olduğu görülür. Hz. Ömer, el-faruk, adil, nizâmı'l-erbain emir'ül-müminîn lakaplarıyla anılmıştır. Bununla birlikte daha ziyade âdil, emirü'l-mü'minîn ve özellikle hak ve batılı birbirinden ayıran manasında "faruk" unvanıyla özdeşleştiğini görürüz.

\section{"Hazreti Fârûk-ı a'zam sahib-i adl ü kerem}

Maden-i lütf ü himem ser-sadri eshab-ı vefa” (Ak, 2009: 37).

Adile Sultan'ın yukarıdaki beytinde Hz. Ömer'e özellikle adaleti vesilesiyle telmihte bulunulmuştur. Vefalı ashabın en önemlilerinden olduğu ifade edilerek, onun lütuf madeni olduğu belirtilmiştir. Beyitte hazreti saygıdeğer efendim, faruk doğru ile yanlışı ayıran, a'zam büyük olan sahib-i adl ü kerem adalet ve kerem sahibi olan, maden-i lütf ü himem lütuf madenin himmeti, sadri eshab-ı vefa vefalı sahabelerin göğsü manasında kullanılmıştır. Terkiplerin geneline bakıldığında “ $\ddot{u} ”$ Farsça bağlacının kullanılıp tamlamaların oluşturulduğu görülür. 
"Oldı kurkincı bulara ol emin

Didiler ana nizam'ul erbain" (Kurt, 2015: 117).

Bu beyitte de Hz. Ömer'in İslam'a girmesiyle birlikte Müslümanların sayıca kırk kişiye vardıklarına işaret edilmiştir. Burada kırk nizamını sağlayan "nizam 'ul erbain" lakabı kullanılarak Hz. Ömer'in aynı zamanda Müslümanların gücüne güç kattığı da belirtilmek istenmiştir. Bilindiği gibi müslümanlar Hz. Ömer İslam'a girdikten sonra namazı açıktan kılmaya başlamış ve kendilerinden emin bir şekilde hareket etmeye başlamışlardır. Beyitte emin sağlam olan, nizam 'ul erbain kelimesi de nadir olan Arapça terkip şekliyle yansıtılarak kırkıncı manasında kullanılmıştır.

Halifelerin üçüncüsü olan Hz. Osman edebiyatımızda daha çok hayâ sahibi ve Efendimizin damadı oluşuyla yer edinmiştir. Divan şiirinde Hz. Osman için, hayâ, hilm, refik ve zu'n-nureyn ünvanlarıyla telmihte bulunulduğu görülür. Hz. Muhammed (s.a.v.)'in iki kızıyla evlendiği için özellikte "zu'n-nureyn" ve edebiyle de "hayâa" lakabıyla şiirde geçmektedir.

\section{"Hazret-i Osman-ı zi'n-nureyn ol kân-ı vefâ}

Hâk-i pâyinden melekler de ederdi hayâ" (Ak, 2009: 40).

Adile Sultan divanından alınan yukarıdaki beyitte Hz. Osman'ın yumuşak huylu ve terbiyesinden meleklerin bile onun bastığı yerlere basmaktan hayâ ettikleri belirtilmiştir. Hazret- $i$ saygıdeğer, zu veya zi sahip olan, nureyn iki nur, zi'n-nureyn iki nur sahibi yani Efendimizin iki kızıyla evlenen, vefa sadık olan, hayâ edep-utangaçlık manasında kullanılmıştır.

Divan edebiyatında kendisinden en çok bahsedilen Hz. Ali ilmi, cesareti, Peygamberimize yakınlığı ve daha birçok meziyetiyle anılmıştır. Hz. Ali, şîr-i Huda, Murtaza, sahib-i düldül, haydar, esedüllah, zevcü'l-Betül ve bab-ı ilm unvanlarıyla edebiyatımızda geniş bir yer kaplamaktadır. Hz. Ali ve oğulları Hasan ile Hüseyin'in katledilmeleri diğer edebiyatlarda olduğu gibi Türk edebiyatında da "maktel" geleneğinin oluşmasına zemin hazırlamıştır. Esedüllah, haydar, bab-ı ilm gibi lakaplar Hz. Ali için en çok kullanılanlardır.

\section{"Bâb-i ilmimiş Aliyyü Murtaza}

Dinle ilminden diyem bir söz size” (Kurt, 2015: 120).

Beyitlerinde de Hz. Ali'nin özellikle ilmine atıfta bulunmuş, ilmin kapısı olduğu belirtilmiştir. Vasıflandırmaların çoğunda rivayet edilen hadisler ve kıssalar etken olmuştur. Burada da şairin, Efendimizden rivayet edilen "Ali ilmin kapısıdır” (Tirmizî, Menâkıb:20). Hadisinden esinlendiğini ifade etmek yerinde olacaktır. Ayrıca "Lâ fetâ illâ Alî, lâ seyfe illâ Zülfikâr " Özmen, 2015: 315). Sözüne binaen de divan edebiyatında Hz. Ali ile ilgili birçok beytin yazıldığı görülür. Beyitte Bâb kapı, ilim Türkçede bilinen ilim, bilgi manasıyla, murtaza ise kendisinden razı olunan kimse manasında beyitte yerini bulmuştur. Bâb-i ilmimiş Farsça terkip şeklinde, Türkçe 'miş' geçmiş zamanın hikâye ekiyle kullanılmıştır. Dolayısıyla bir tamlamada hem Türkçe hem de Farsça dil özellikleri bir arada kullanılmıştır.

Hz. Muhammed (s.a.v)'in amcası olan Hz. Hamza da mertliği ve cesareti ile tanınmış ve divan edebiyatına bu vasıflarıyla konu olmuştur. Uhud savaşında Ebu Süfyan'ın eşi Hind'in görevlendirdiği Vahşi adında bir köle tarafından sırtından vurularak şehit edilmiştir. Diğer dört halifeden farklı olarak Hz. Hamza için divan edebiyatında mertliği, cesareti ve gazveleri konu alan “Hamzanameler"'in yazıldığı görülür. 
"Şehid oldi önünde ahır anun

Nitekim Hamza Fahr-ı enbiyanın” (Yüksel, 2010: 283).

Yukarıdaki beyitte Hz. Hamza'nın şehadeti ve onun enbiyanın iftiharı olduğu dile getirilmiştir. Beyitte ahır son, fahr övünç, enbiya peygamberler, fahr-ı enbiya ise Farsça terkip vasıtasıyla enbiyanın iftiharı manasında kullanılmıştır.

\title{
Hz. Hasan ile Hz. Hüseyin'i Anlatan Şiirler
}

Peygamber Efendimizin torunları olan Hz. Hasan ve Hz. Hüseyin ehl-i beytten ve imamlardan oluşları, Hz. Hasan'ın zehirleniși ve Hz. Hüseyin'in Kerbela'da katli üzerine kendilerine mersiyeler yazılmıştır. Bu tür mersiyelere İran edebiyatında daha çok rastlanmakla beraber, aynı durumun kendine has bir üslupla Türk edebiyatında da hemen hemen aynı seviyede görüldüğ̈̈ ifade edilebilir.

\author{
"Musibet-i Hasan u mihnet-i Hüseyn-i şehid \\ Demî ki oldı gam-efzayı tab'-ı pâk-ı Resûl \\ Teselli-yi dil-i pâk-ı Resûl içün Hakdan \\ Beyan-ı kıssa-yı Ya'kub u Yusuf itdi nüzul”' (Tany1ldı, 2016, 146).
}

Fuzûlî'nin Hadîkatus's-Su 'adâ'sından alıntılanmış olan yukarıdaki beyitlerde, Hz. Hasan ile Hz. Hüseyin'in şehit edileceğinin haber verilmesi üzerine hayli üzülen Peygamberimizi teselli etmek için Yusuf süresinin indirildiği belirtilmiştir. Musibet büyük sıkıntı, mihnet üzüntü, şehit Allah yolunda canını feda eden kişi, tab' insan tabiatı, yaratılış ve huy manalarında, teselli avuntu, resul gönderilen elçi, beyan bildirmek, kıssa olay ve nüzul indirmek manasında kullanılmıştır. Beyitlerde çoğu kelimenin Arapça olduğu görülür. $\mathrm{Bu}$ kelimelerin silinmesi hâlinde şiirin tamamen ortadan kalkacağını belirtmek abartı olmayacaktır. Terkibin kısmen Arapça kısmen de Farsça olduğu gözlerden kaçmaz.

\section{Aşk, Hayal, Sevgili ve Rakip Gibi Mefhumları Yansıtan Beyitler}

Dini literatür dışında Divan edebiyatından farklı beyitler üzerinden örneklerle konuya değinip söz konusu çerçevede Arapça kelimeleri tahlil edeceğiz. Divan şiirinin geneline bakıldığında hemen hemen her bir mısrada Arapçadan kelimelerin mevcudiyetini rahat bir şekilde görürüz.

\footnotetext{
"Sefer it derdüne tîmâr ola şâyed Nev'î

Bâis-i sıhhat olur eylese bîmâr sefer" (Solmaz, 2005: 136).
}

Hasta, nerede bir tabip olduğunu öğrense oraya gitmek ister. Hatta derdinin devasının orada olmadığını bilse bile, bir umutla gider. Bu beyitte sevgilinin hasta gönüllerin derdine derman olacağı üzerinde durulmuştur. Beyitte sefer arayış, bais-i sıhhat sağlık veren manasında Farsça terkip şeklinde kullanılmıştır. Bâis kelimesi aslen gönderen manasında olup burada anlam kaymasıyla, veren şeklinde geçmektedir.

Aşağıdaki beyitte de şi’r şiir, lafz-ı garib değişik tarz, nüsha-i kamus sözlük manasında ama Farsça terkip üslubuyla kullanılmıştır.

“Ey şi'r miyânında satan lafz-ı garîbi

Divân-ı gazel nüsha-i kamus değildir" (Gözütok, 2000: 3). 
Nabi bu beytiyle şunu demek ister: Ey şiirde alışılmadık, garip kelimeler kullanan! Şunu bil ki şiir kitabı sözlük değildir. Dolayısıyla şiirdeki kelimelerin halkın tanıdığı, bildiği kelimeler olması gerektiğini savunur. Ey seslenme edatı, şi'r şiir, lafz kelime, garib yabancı manasında olup burada değişik manasıyla yerini bulmuştur. Gazel aşk şiiri, nüsha-i kamus sözlük metni manalarında kullanılmıştır.

"Hayâl-i zülfün olsun mün'akis âyîne-i kalbe

Misâl-i şi’r-i rengînüm şebistân-ı hayâl olsun” (Erkal, 2009: 41).

Nâbî, bu beytinde Arapça kelimeleri, hayâl düşünde, mün'akis yansıma, kalb kalp, misâl-i şi' $r$ - $i$ şiir gibi manalarında kullanarak doğadaki varlık ve olguların şairin gönül aynasına çarparak bunların geri yansıması şeklinde değerlendirip burada şairin fonksiyonunu, doğal olarak da şiirin işlevlerini göz önüne sermiş oluyor.

"Bi-nikab olma habibim görmesin yüzün rakib

Mushaf açık olıcak derler anı şeytan okur” (Tarlan, 1992: 125).

Şâir Necati bu beyitte, sevgilinin yüzünü rakibin örtüsüz görmesini istemez. Rakibi şeytana sevgilinin yüzünü Mushaf'a (Kur'an'a) benzetir. Kur'an açık bırakılırsa şeytanın onu okuyacağı inancına telmihte bulunur. Beyitte nikab kelimesi "bi” Farsça olumsuzluk ekiyle kullanılarak örtüsüz, habibim kelimesi Türkçe "im” tamlanan ekiyle sevgilim, rakip karşı taraf, mushaf Kur'an, şeytan Türkçede bilinen manasıyla ateşten yaratılan yaratık manasında kullanılmıştır.

"Yă̆sa bârân gibi gökten katarât-ı âmâl

Yine bed-tâli' olan hâ'ib ü hâsir bulunur” (Levend, 2015a: 96).

Şair Nabi yukarıdaki beytinde kişinin eline kısmetinden daha fazla bir şeyin geçmeyeceğini, mücadelenin beyhude olacağını ve talihe boyun eğilmesi gerektiğini ifade eder. Beyitte katarât-ı âmâl Farsça terkiple emel damlaları, bed-tâli' Farsça kötü kelimesiyle birlikte kötü talih, hâ'ib ü hâsir boş ve kaybetmiş manalarında kullanılmıştır.

Ünlü şair Baki’ye ait olan aşağıdaki beyitlerde de hem aruzun hem de musikinin hâsıl olabilmesi için Türkçe kelimeler yerine Arapça kelimeler kullanılmıştır.

"Ezelden şâh-ı 'aşkun bende-i fermânıyuz cânâ

Mahabbet mülkinün sultan-ı âlî-şânıyuz cânâ" (Şenödeyici, 2015: 416).

Ey sevgili! Biz ezelden beri aşk sultanının buyruklarının kuluyuz. Bu yüzden de aşk ülkesinin anlı şanlı sultanıyız. Beyte bakıldığında ezel kelimesi den ayrılma hâli ile kullanılmışken, ikinci beytin canan kelimesi hariç diğer kelimelerin Arapça kelimelerden oluştuğu görülür. Fakat burada dikkat çeken olgu terkiplerin Farsça üslupla oluşturulmuş olmasıdır. Mahabbet sevgi, mülk ülke, sultan-ı âlı̂ de yüksek mevki manasında kullanılmıştır. Kelimelerin bu şekilde kullanılması hem yüksek düzeyde dil bilgisi hem de derin şiir ve his zevkini gerektirir.

"Çıkalı göklere âhum şereri döne döne

Yandı kandîl-i sipihrün cigeri döne döne” (Tarlan, 1992: 37).

Ahımın kıvılcımları göklere çıktığından beri, felek kandilinin ciğeri döne döne yandı. Beyitte şerer kıvılcım, kandîl 1şık manasında kullanılmış ve ayrıca kandîl kelimesi Farsça bir kelimeyle tamlama hâlinde şiirde yerini bulmuştur. 
“işittim ki rakip ölmüs habibin ömrü çoğ olsun

Kapıdan bir seg eksilmiş anı sanman ziyanlıdır" (Batislam, 2003:196).

Duydum ki rakip ölmüş sevgilinin ömrü çok olsun. Onun zarara uğradığını sanmayın sakın, kapıdan bir köpek eksilmiştir. Şair Necâtî beytinde rakip kelimesini düşman, habib kelimesini sevgili manasında ve "in" tamlayan eki ile "sevgilinin" șeklinde kullanılmış, ömr kelimesi de yaşam manasıyla ve " $\ddot{u}$ " tamlanan ekiyle onun ömrü manasında, dolayısıyla her iki Arapça kelimeye tamlayan ve tamlanan ekleri eklenerek tamlama oluşturulmuştur. Ziyan kelimesini de zarar manasında kullanmıștır. Arapçadaki erillik dișilik mefhumu bu şekilde bir tasarrufu gerektirmektedir. Fakat burada şairin hangi düşünceyle bu şelikde bir kullanıma gittiği bilinmemektedir.

Bahar tasvirinin yapıldığı aşağıdaki beyitlerde Türkçe fiillerle Arapça ve Farsça kelimelerin mozaiği andırır bir şekilde kullanılması müthiş bir kültür birikimin yansıtımıdır.

"Oldı havalar mu'tedil irdi bahar dilkaşe

Sürsûn safâsın âlemin zevk itsun erbab-ı safâ” (İz, 2016: 322).

Şair Ruhi, havaların ısınıp çekici bir hâle geldiğini ve bu durumdan sefa ile zevk sahiplerinin istifade etmeleri gerektiğini belirtir. Mu'tedil orta ısınmış, safa ve zevk eğlence manasında kullanılmıştır. Erbab kelimesi de işinin ehli olan kişiler manasında kullanılarak terkipte zevk ve seğlence ehli olanlar şeklinde yerini bulmuştur. Âlem ise hayat manasında kullanılmıştır. Âlemin Arapçadaki diğer manaları ise dünya, insanlık ve topluluktur. Âlem kelimesi Türkçe "in" tamlayan ekini alarak âlemin sefası şeklinde bir tamlama oluşturulmuştur.

Yine şair Ruhi'ye ait olan ve yergi içeren aşağıdaki mısralarda Arapça kelimelerin aşırı kullanımı dikkat çeker.

"Gör zâhidi kim sâhib-i irşâd olayın dir

Dün mektebe vardı bu gün üstâd olayın dir” (Macit, 2015: 339).

Şair beyitlerinde insanları hak yoluna davet etmek isteyen ama cahil olup alimlik iddiasında bulunan zühhadı şiddetle eleştirir. Beyitte zâhid ibadet eden, sâhib-i irşâd Farsça dil kurallarına göre birleştirilerek doğru yola davet eden kişi, mekteb okul-eğitim görülen yer, üstâd ise öğretici manasında kullanılmıştır.

"Ben aşıkun dururken sırsun ser-i rakibi

Ey seng-dil mürüvvet bu inkisara yer yok” (Kurnaz, 2012:422).

Ey taş kalpli sevgili seni seven aşkın duruken rakip için sır olacaksın, yiğitlikte kırılmaya, vazgeçemeye yer yoktur. Beyitte âşı seven kişi, sır gizli manasında, rakib karşı taraf, mürüvvet yiğitlik, inkisar gücenme, kırılma manasında kullanılmıştır. Ayrıca rakib kelimesi Farsça bir kelimeyle tamlama oluşturmuştur. Aşıkun, "un" tamlanan ekini ve sırsun "sun" ikinci tekil şahıs ekini alarak "sen-senin" manasını oluşturmuştur.

Uyarı mahiyetinde olan aşağıdaki beyitte intihal (çalmak) yapan kişilerin hükümlerinin nasıl olması gerektiği üzerinde durulmuştur.

"Sirkat-i şi'r idene kat'-ı zebân lâzımdur

Böyledür şer'-i belâgatda fetâvâ-yı sühan” (Levend, 2015b: 79). 
Sünbül-zade Vehbi mısralarında, başkalarının şiirini çalan kişilerin dillerinin kesilmesi gerektiğini çünkü bunun edebiyat kanunlarına göre sözün, kelamın bir gereği olduğunu ifade eder. Sirkat çalmak, Sirkat-i şi'r şiirin çalınması manasında Farsça bir terkiple, kat' kesmek, lâzım gereklilik, şer'-i belâgat Belağatın kanunu manasında Farsça bir terkiple, fetâvâ ise gene bir Farsça kelimeyle tamlama oluşturularak, söylenen ve kesinleşen manasında kullanılmıştır.

\section{İktibas Yoluyla Alınan Kelimeler}

Aşağıdaki beyitte peygamberimizin yol arkadaşı olan Hz. Ebubekir'e telmihte bulunulmuş ve olay bağlamında Kur'an-1 Kerim'den bir ayet nakledilmiştir.

"Kim Rasûliyle nice ol yârdur

Sânî isneyni iz hüma fi'l-gardur" (Kurt, 2015:116).

Görüldüğü gibi beyitte Hazreti Ebubekir'in, Efendimizin Mekke'den Medine’ye göç ederken onun mağara arkadaşı olduğuna telmihte bulunularak, Peygamberimiz ve Hz. Ebubekir'in mağarada oluşlarına değinilmiştir. Rasûl gönderilen, elçi manasında, sânî ikinci, isneyn iki, iz hani veya iken, hüma o ikisi, fi içinde, gar mağara manasındadır. "Sânî isneyni iz hüma fì'l-gardur" (Tevbe, 9/40) ayeti tamamen iktibas sanatıyla alıntılanmıştır. Mısranın tamamı Arapça kelimelerden oluşan beyitte mağarada bulunan iki kişiden ikincisiydi, ibaresiyle Peygamber Efendimiz kastedilmiştir. İkisinin mağarada oluşlarının anlatıldığı beyyitte 'dur' bildirme eki kullanılmış olup mısraya kesinlik anlamı katılmıştır.

"Ve lâ-tulkû bi-eydîkum ile't-tehlüketi

Buyurdı Hazret-i Mevlâ Efendi bunı bilindi" (Çelik, 2017: 310).

Yukarıdaki beyitte "kendi ellerinizle kendinizi tehlikeye atmayını"” (Bakara, 2/195) mealindeki ayet ile Bakara süresinden yapılan kısmi bir iktibasla hem hatırlatma ve uyarma hem de ayete telmihte bulunulmuştur. Ve lâ asla, tulkî atmak, bi-eydîkum ellerinizle, ile't-tehlüketi tehlikeye, Hazret-i Mevlâ yüce yaratan manasında kullanılmış ve bu tarzla aynı zamanda aruz kalıbı uygun bir şekilde uygulanmıştır.

"Hemân rahm idene rahm ider

Allâh buyurdl irhamû men eyle her gâh" (Çelik, 2017: 319).

Bu beyitte de Peygamber Efendimizin "Yeryüzündekilere rahmet edin ki, göktekiler de size merhamet etsin." (Ebû Dâvûd, Edeb:58; Tirmizî, Birr: 16) hadis-i şerifine telmihte bulunulmuştur. Böylece müminlerin arasındaki bağın, sevginin ve saygının güçlenmesi hedeflenmiştir. İrhamû kelimesi rahmet edin, acıyın manasında kullanılmış olup rahmet manasındaki rahm sözcügüüle aynı kökten gelmektedir.

\section{"Gider gururı sakın ateşî mizaç olma \\ Yeter çü Âdem olana halaktehu min tîn” (Çavuşoğlu, 1983: 82).}

Beyitte insanların çamurdan, şeytanın ateşten yaratıldığını belirten ayetin bir kısmı iktibas edilerek şeytanı Hz. Âdem'e secde etmesine engel olan gururdan sakınılması ve ateş mizaçlı olunmaması gerektiği belirtilir. Dolayısıyla Araf süresinin "Dedi ki, sana emrettiğim hâlde seni secde etmekten men eden ne, (cevaben) dedi ki, ben ondan (Âdem'den) daha haytrlyytm beni 
ateşten onu topraktan yarattın." (A'raf, 7/12) mealindeki ayetin son kısmı iktibas edilmiştir. Halaktehu min tîn terkibi tamamen Arapça olup onu çamurdan veya topraktan yarattın manasındadır. Gurur ve mizaç kelimeleri de Türkçede kullanılan manalarıyla kullanılmıştır.

\section{Tamamen Arapça Olan Beyitler}

Arapça kelimelerin bazen tüm beyit şeklinde de karşımıza çıktı̆ğ görülür. Şair Lutfi'ye ait olan aşağıdaki beyitte Efendimiz (s.a.v) tamamen Arapça kelimelerle methedilmiştir.

"Sultan-ı memâlik-i hakîkat

Bürhân-ı mesâlik-i tarîkat” (Tanyıldız, 2013: 36).

Mısralarında Efendimizin (s.a.v) hakikat mülkünün sultanı ve Allah'a ulaşmanın yollarına vakıf olup kendisinin de bunun delili olduğu ifade edilmiştir. Beyitte tüm kelimelerin Arapça olduğu ancak terkip üslubunun Farsça olduğu görülmektedir. Sultan bir devletin lideri veya kâinatın yaratıcısı Allah veya beyitte olduğu gibi gerçekliğin yegâne mümessili Peygamberimize atfen kullanılmıştır. Memâlik ${ }^{2}$ kelimesi gerçekte memleketler (devletler) manasında iken burada mülk olarak kullanılmış ve kısmi bir anlam değişimine uğramıştır. Hakîkat gerçek olan, bürhân kanıt, beyitte lider manasıyla kullanılarak anlam genişlemesine uğramıştır. Mesâlik geçilecek yollar, tarîkat yol, yöntem manasında kullanılmıştır.

Sultan Abdülhamid'in methedilip kendisine dualar okunduğu Alî Emîrî Efendî’nin (ö.1924) Levâmi' el-Hamîlîye'sinden alınan aşağıdaki beyitlerde Arapçada okunan dualar tamamen iktibas yoluyla şiire beyit olarak seçilmiştir. (Alî Emîrî, 32-33).

“Veffeka'l-llâhu cemî'a mâ yeşe-u mâ yedûm

Yessere'l-llâhu karîben mâ yuhibbu mâ yurîd",

"Hellede'l-llâhu ve ebkâh-u ile yevmil kiyâm

'Ammere'l-llâhu ve kavvâh-u ile yevmil ve'îd"4

\section{Aruz Kalıbının Beyitlere Uydurulması ve Kafiyenin Sağlanması}

Arapça kelimelerin şiirde kullanılmasının bir diğer sebebi de aruz kalıbının Divan şiirine uyarlanmasıyla ilgilidir. Aruz kalıbının şiire tam uydurulabilmesi için çoğu mısrada Türkçe karşılı̆̆ olan kelimelerin dahi yerine ya Arapça ya da Farsça kelimelerin kullanıldığı görülür.

\section{"Öyle mu'tâd olubam âteş-i hicrânuna kim}

Görmesem yandurur elbette meni hicrânı” (Solmaz, 2004: 43).

Beytinde aruzun "Fe'ilâtün Fe'ilâtün Fe'ilâtün Fe'ilün" kalıbı kullanılmıştır. Gazelde vezin gereği mu'tâd, hicrânuna kelimelerinin yerine Türkçe alışılmış ve ayrılık kelimelerinin kullanılmasına imkân yoktur. Günümüzde bilinen bu kelimelerin kullanılması hâlinde aruz kalıbında sağlanan uyumun tamamen bozulacağını görürüz. Mu'tâd alışılmış, hicrân ayrılık, elbette ise kesinlikle manasında kullanılmıştır. Hicrân kelimesi " $u n$ " aitlik eki, " $a$ " yönelme hâl eki ve "”" belirtme hâl ekiyle birlikte kullanılmıştır.

\footnotetext{
${ }^{2}$ Memalik; bu kelimenin tekili memleke olup (devlet), çoğulu memâlik (devletler)dir.

3 "Allah onu yaşadığı müddetçe istediği her şeye erdirsin

Allah onu yakında sevdiklerine ve istediklerine erdirsin"

4 "Allah onu kıyamet gününe kadar ebedi ve baki kılsın

Allah ona vadedilen güne kadar ömür ve güç versin"
} 
"Müheyyâ oldı meclis sâklyâ peymâneler dönsün

Bu bezm-i ruh-bahşûn şevkine mestâneler dönsün” (Doğan, 2013: 41).

Şair Bâkî̀ye (ö.1600) ait olan yukarıdaki beyitte "Mefâ'îlün Mefầîlün Mefầ'ïlün Mefấîlün" kalıbı kullanılmış olup herhangi bir kelimenin değiştirilmesi hâlinde kalıbın uygulanmasının mümkün olamayacağını görürüz. Örneğin "müheyya" kelimesinin yerine "hazır olmak" kelimesini kullandığımızda hem musiki hem de kalıp açısından bir kırılmaya yol açacağını rahatça görürüz. Müheyyâ hazır olmak, meclis toplanılan yer, sâkı şarabı sunan kişi, ruh Türkçede bilinen manasıyla, şevk özlem manasında kullanılmıştır. Bâkî beytinde eğlence meclisinin hazır olduğunu ve şarabı sunan kişiye kadehleri dağıtması gerektiğini söyler. Ayrıca ruhen kendinden geçmiş olanların artık raksa kalkmaları gerektiğini ekleyerek beytini tamamlar.

"Muntazır oldl vasluna hasret ü derdi çoh gönül

Hoş degül ant yandurub va'de-i intizâre gel” (Doğan, 2013: 193).

XIV. yüzyılda yaşamış şair Nesmi'ye ait olan beyitlerde “Müfte'ilïn Mefầilün Müfte'ilün Mefầilün” kalıbı kullanılmış olup bahsi geçen kelimlerin değiştirilmesi hâlinde hem kalıbın hem de beyitteki musiki havanın ortadan kalkacağını görürüz. Nesimi beytinde gönlün beklemekle derde ve hasrete garkolduğunu, bunun kendisini helak ettiğini, sevgilinin sözleşilmiş zamanda gelmesi gerektiğini ifade eder. Muntazır bekleyen, vasıl kavuşmak, hasret büyük özlem, va'de kararlaştırılan an, intizâr bekleyiş manasında kullanılmıştır. Görüldüğü üzere terkipler Farsça bir üslupla yapılmıştır.

Divan edebiyatının asli unsurlarından olan Kuran, hadis ve sünnetin de Divan şiirinde kelime seçimini azami derecede etkilediğini görürüz. İnanca bağlı coğrafî adlar da kelime seçiminde önemli bir rol oynarken, aşağıdaki beyitte inanç ve coğrafî şartlar karşımıza çıkıyor.

"Gözi yaşlu gider dầim Necâtî kûy-ı cânâna

Tarîk-ı Ka'be müşkildür kamu yirlerde âb olmaz”'(Solmaz, 2004: 48).

Necâti, sevgilinin mahallesine daima gözü yaşlı olarak gider, çünkü Kâbe yolları çetindir, her yerde su bulunmaz. Beyitte dâ'im devaml, tarîk-ı Ka'be Kâbe yolu, müşkil çetin ve zor manasında kullanılmıştır. Yine bu kelimelerin değiştirilmesi şiirde hem musiki hem de kalıp açısından bazı özelliklerin kaybedilmesine sebep olacaktır.

Aşağıdaki beyitte de kalıbın ve ahengin sağlanması için Arapça kelimeler kullanılmıştır.

"Cevrine mu'tâd olan bûy-ı vefâ kımaz recâ

Hârdan havf iden olmaz tâlib-i sevdâ-yl gül”"(Mermer, 2009: 207).

Senin eziyetine alışmış olan, vefa kokusu istemez, nitekim dikenden korkusu olan da gülün sevdasına talip olmaz. Beyitte cevr eziyet, sıkıntı manasında, mu'tâd alışmış, vefa bağlılık, recâ arzu, havf korku, tâlib isteyen, sevda kara olan şey olup "د, و, و" harflerinden türemiştir. Beyitte ise tutku manasında kullanılmıştır. "Bûy-ı vefâ ve tâlib-i sevdâ-yl" terkipleri de Farsça dil kurallarına göre yapılmıştır.

Klasik Türk şiirinin can çekiştiği son dönmelerde dahi şiirin göz için mi yoksa kulak için mi yazılması gerektiği tartışması da Arapça kelimeler üzerinden gerçekleşir. Türk edebiyatında 
“Abes-Muktebes Tartışması” olarak bilinen bu meşhur tartışma şiirde ve genel olarak edebî zevk anlayışında büyük ayrışmaların oluşmasına sebep olur.

"Zerre-i nurundan iken muktebes

Mihr ü mehe bakmak abes" (Korkmaz, 2009: 136).

Tartışmaya konu olan kelimeler, güzelliğini başkasından alan manasına gelen muktebes kelimesinin sonundaki harfin normal w ve oyalanma, boş vakit geçirmek manasında olan abes kelimesinin sonundaki harfin ise peltek ث ile yazılmasıdır. Bunun neticesinde, şiiri yazan Hasan Asaf' a yapılan kafiyeyi bilmediği yönündeki suçlamalar "eski-yeni” şiir taraftarlarının oluşmasına ve şiddetli tartışmaların cereyan etmesine sebep olmuştur. Zerre-i nurun, güzelliğinin çok azı manasında kullanılmıştır. Dolayısıyla ay ve güneş parlaklıklarını, güzelliklerini senin güzelliğinin küçücük bir kısmından almışken, onlara bakmanın, esas olan sevdiğinin güzelliği varken, boş bir uğraş olduğu ifade edilmiştir.

\title{
Modern Şiirden Örnekler
}

Türk edebiyatında Tanzimat döneminin en önemli kasidelerinden biri olan şair Namık Kemal'in "Hürriyet Kasidesi”ndeki Arapça kelimeler çıkartıldı̆̆ 1 takdirde kasidenin anlam bütünlügünün ciddi bir şekilde zedeleneceği aşikârdır. Arapça kelimelerin Türk şiirinde bu denli bir otoriteye sahip olması asırlar boyu birlikte yaşanmışlığın ve kültür alışverişinin bir neticesidir. Şüphesiz bu kelimeler artık birer Türkçe kelime özelliğindendir. Yaklaşık on asırdır kullanılan bu kelime ve ibareleri dışlamak kültür yıkımından başka bir şey değildir. Aşağıda bold olarak gösterdiğimiz kelimeler Arapça kökenli kelimelerdir.

“Mefầî̉in Mefâ'îlün Mefâ'îlün Mefâ'îlün”

\author{
Görüp ahkâm-ı asrı münharif sıdk u selâmetten \\ Çekildik izzet ü ikbal ile bâb-ı hükûmetten \\ Usanmaz kendini insan bilenler halka hizmetten \\ Mürüvvet-mend olan mazluma el çekmez iânetten \\ Hakîr olduysa millet, şânına noksan gelir sanma \\ Yere düşmekle cevher, sâkıt olmaz kadr-ü kıymetten \\ Vücûdun kim hamir-i mâyesi hâk-i vatandandır \\ Ne gâm râh-l vatanda hak olursa cevr ü mihnetten. \\ Muini zâlimin dünyada erbâb- $\imath^{5}$ denaettir \\ Köpektir zevk alan, sayyâd-ı bi-insâfa hizmetten \\ Hemen bir feyz-i bâkî terk eder bir zevk-i fânîye \\ Hayatın kadrini âli bilenler, hüsn-i şöhretten. \\ Nedendir halkta tul-i hayata bunca rağbetler \\ Nedir insana bilmem menfaat hifz-l emanetten. \\ Cihanda kendini her ferdden alçak görür ol kim \\ Utanmaz kendi nefsinden de ar eyler melametten \\ Felekten intikam almak, demektir ehl-i idrâke \\ Edip tezyid-i gayret müstefid olmak nedâmetten \\ Durup ahkâm-ı nusret ittihâd-ı kalb-i millette \\ Çıkar âsâr-ı rahmet, ihtilaf-ı rey-i ümmetten \\ Eder tedvîr-i âlem bir mekînin kuvve-i azmi
}

${ }^{5}$ Erbâb: Burada "kişiler" manasında kullanılmıştır, aslı rabbin çoğu olan "rabler" dir. 
Cihân titrer sebât-ı pây-ı erbâb-ı metânetten

Kaza her feyzini her lutfunu bir vakt için saklar

Fütur etme sakın milletteki za'f u betaetten

Değildir şîr-i der-zencire töhmet acz-i akdamı

Felekte baht utansin bi-nasib-erbab-ı himmetten

Ziya dûr ise evc-i rif'atinden izturâridir

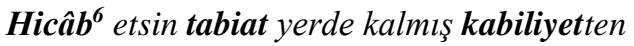

Biz ol nesl-i kerîm-i dûde-i Osmaniyânız kim

Muhammerdir serâpâ mâyemiz hûn-ı hamiyetten

Biz ol âl-i himem erbâb-ı cidd ü içtihâdız kim

Cihangirâne bir devlet çıkardık bir aşiretten

Biz ol ulvi-nihâdânız ki meydân-ı hamiyette

Bize hâk-i mezar ehven gelir hâk-i mezelletten

Ne gam pür âteş-i hevl olsa da gavgâ-yı hürriyet

Kaçar mı merd olan bir can için meydân-l gayretten

Kemend-i can-güdâz-ı ejder-i kahr olsa cellâdın

Müreccahtır yine bin kerre zencîr-i esâretten

Felek her türlü esbâb-ı cefasin toplasın gelsin

Dönersem kahbeyim millet yolunda bir azîmetten

Anılsın meslĕgimde çektiğim cevr ü meşakkatler

Ki ednâ zevki âlâdır vezâretten sadâretten

Vatan bir bî-vefâ nâzende-i tannâza dönmüş kim

Ayırmaz sâdıkân-ı aşkını âlâm-ı gurbetten

Müberrâyım recâ vü havfden indimde âlidir

Vazifem menfaatten hakkım agrâz-ı hükümetten

Civânmerdân-ı milletle hazer gavgâdan ey bidâd

Erir şemşîr-i zulmün âteş-i hûn-i hamiyetten

Ne mümkün zulm ile bidâd ile imhâ-yı hürriyet

Çalış idrâki kaldır muktedirsen âdemiyetten

Gönülde cevher-i elmâsa benzer cevher-i gayret

Ezilmez şiddet-i tazyikten te'sir-i sıkletten

Ne efsunkâr imişsin ah ey didâr-ı hürriyet

Esîr-i aşkın olduk gerçi kurtulduk esâretten

Senindir şimdi cezb-i kalbe kudret setr-i hüsn etme

Cemâlin ta ebed dûr olmasın enzâr-ı ümmetten

Ne yâr-ı cân imişsin ah ey ümmid-i istikbâl

Cihant sensin azad eyleyen bin ye's ü mihnetten

Senindir devr-i devlet hükmünü dünyaya infâz et

Hüdâ ikbâlini hıfzeylesin hür türlü âfetten

Kilâb-ı zulme kaldı gezdiğin nâzende sahrâlar

Uyan ey yâreli şîr-i jeyân bu hâb-ı gafletten (Kaplan, 1999: 37-41).

Aşağıda da Yahya Kemal Beyatlı'nın Süleymaniye'de Bayram Sabahı adlı şiirinin ilk iki bölümündeki Arapça ağırlıkta yabancı kelimeleri görmekteyiz. Kaplanın ifadesiyle "O kelimeler çıkarılınca Yahya Kemal'in o güzelim şiiri güveler tarafından yenilmiş gibi olmuyor mu?” Şiirin geneline bakıldığında Arapça ve Farsça kelimelerin Türkçe ilgi, iyelik ve hâl ekleriyle birlikte kullanıldığını görmekteyiz.

\footnotetext{
${ }^{6}$ Hicâb: Şiirde utanmak masında kullanılmıştır, aslı “örtü” dür.
} 
“Fe'ilâtün Fe'ilâtün Fe'ilâtün Fe'ilün”

Artarak gönlümün aydınlığı her saniyede ${ }^{7}$

Bir mehâbetli sabah oldu Süleymâniye'de

Kendi gök kubbemiz altında bu bayram saati,

Dokuz asrında bütün halkl, bütün memleketi

Yer yer aksettiriyor mavileşen manzaradan,

Kalkıyor tozlu zaman perdesi her an aradan.

Gecenin bitmeye yüz tuttuğu andan beridir,

Duyulan gökte kanat, yerde ayak sesleridir.

Bir geliş var! Ne mübârek, ne garîb âlem bu!

Hava boydan boya binlerce hayâletle dolu..

Her ufuktan bu geliş eski seferlerdendir;

O seferlerle açılmış nice yerlerdendir.

Bu sükûnette karıştıkça karanlıkla ışık

Yürüyor, durmadan, insan ve hayâlet karışık;

Kimi gökten, kimi yerden üşüşüp her kapıya,

Giriyor, birbiri ardınca, ilâhî yapıya.

Tanrının mâbedi her bir tarafindan doluyor,

Bu saatlerde Süleymâniye târih oluyor.

Ordu-milletlerin en çok döğüşen, en sarpı

Adamış sevdiği Allah`ına bir böyle yapı.

En güzel mâbedi olsun diye en son dînin

Budur öz şekli hayâl ettiği mîmârînin. (Kaplan, 2006: 213-214).

$\mathrm{Bu}$ şekilde bir dilin esas metinlerine yapı taşı olmuş kelimeler, toplumun öz değerleriyle birleşip mükemmel bir harmanı oluşturarak var olan kültürün yansıtıcısı olmuştur. Bu kelimeler kökleri ve yapıları bakımından yabancı olmakla birlikte yüzyıllardır bir toplumun kullandığ unsurlar şeklinde dilde yerini bulmuş ve artık Türkçeleşerek, dilin asli uzuvları hâline gelmiştir.

\section{SONUC}

Divan edebiyatı gerek muhit gerek kültür çeşitliliği bağlamında faklılıkları bir potada eritebilmeyi başararak, İslami figürler çerçevesinde gelişmiş ve tekâmülünü bu minvalde sürdürüp çok kültürlülüğü aksettiren imparatorluğun yegâne sanat dili olmuştur. Bu bakış açısıyla Divan edebiyatı şairleri, his ve fikirlerini münferitlikten ziyade çoğulculuğu temsil eden bir üslupla birlikte özel bir sanat dilini vücuda getiren iç dünyalarını, sonraları da tasavvufun etkisiyle ilahi aşkı, hakikat gerçeğini emsalsiz bir vechle aksettiren maddi manevi aşkla asırlardır yoğrulmuş cevher niteliğinde olan kelime, remiz, deyim, hikmetli sözler ile atasözleri gibi kalıpları kullanarak beyitlere yansıtmışlardır.

Divan edebiyatı farklılıkların birleştirildiği bir mozaik taşı vasfında olmakla birlikte kendine has özellikleriyle dikkati çeker. Buna rağmen mütevazılığından hiç bir zaman ödün vermeden oluşumunu tamamlayarak günümüze kadar ulaşmıştır. Bu edebiyatın oluşum coğrafyası, halkaların ilişkileri, savaşlar, anlatılar, dini inanç ve mezhep, kültür farklılığı, yaşam tarzı gibi unsurlar edebiyatın dilini renklilik çerçevesinde bir hayli etkilemiştir. Özellikle beslendiği kaynaklara baktığımızda bu çeşitliliğin kaçınılmaz olduğunu ve bunun Divan edebiyatı için özel bir nitelik olduğunu görmekte zorlanmayız. Kur'an ayetleri ve hadisler, tefsir, kelam, hadis, fikıh

\footnotetext{
${ }^{7}$ Saniyede, Süleymaniye'de, manzaradan, sükûnette, ufkunda vb, bulunma ve ayrılma hâl ekleri kullanılmıştır. Mimariyle, hayaletle kelimelerinde "ile" vasıta eki kullanılmış, mimarinin, vatanın gibi kelimlerde de "nin- ın" tamlayan eki kullanılmıştır.
} 
gibi dini bilgilerin yoğun olduğu dallar, tarihi olaylar, Firdevsi'nin Şehname'si, Allah'a tasavvuf yoluyla ulaşma düşüncesi, evliyaların kerametleri, tarikatlar, dönemin ilim dalları, gelenek ve görenekler, atasözleri, deyimler ve hikmetli sözler Divan edebiyatının beslendiği ana kaynaklardır.

Yukarıda belirtilen unsurların tamamı Divan şiirinin sadece fikri altyapısını değil aynı zamanda dilinin de şekillenmesinde etken rol oynayarak derin bir karışımı ihtiva eden özel bir dilin oluşmasına vasıta olmuştur. Divan şiiri dilinin Arapça kelimeler, Farsça terkipler ve Türkçe fiillerden oluştuğunu işin ehli olan herkes çok iyi bilir. Bu çalışmada Divan şiirinde Arapça kelimelerin varlığından ziyade bu kelimelerin anlamsal değeri ve dil bilgisi bağlamında kulanım şekli üzerinde durulmuştur. Divan şiirine Arapça kelimelerin geçişi farklı yollarla gerçekleşmiş olup bazen anlam daralmasına veya kaymasına uğradığını bazen de anlam genişlemesine sahne olduğunu farklı temaları işleyen beyitler üzerinden tahlil ederek söz konusu kelimelerin anlamsal değerini yansıtmaya çalıştık. Arapça kelimelerin kullanım üslubuna baktığımızda bir kısmının Arapçada olduğu gibi kullanıldığını bir kısmının da Farsça kelime ve eklerle tamlama oluşturularak kullanıldığını diğer bir kısmının da Türkçe ve Farsça şahıs eklerini alarak kullanıldığını tespit ettik. Özellikle Farsça kelimelerle kullanılan Arapça kelimelerin daha çok Fars edebiyatı üzerinden Divan şiirine geçtiğini belirtmekte fayda vardır.

Arapça kelimelerin Divan şiirinde yer bulmasının sebeplerine genel olarak değinmekle beraber, bunun dışında şiirin iç ve dış yapısıyla ilgili sebeplerin de varlığı söz konusudur. Belirli bahirlerden oluşan aruz kalıbının Türk şiirine uygulanılması, kafiye ve redif, nazım şekli ve nazım türü, nazirecilik geleneği, şairin meslekî konumu ve sosyal statüsü ile şiirin sunulduğu kişinin sosyal statüsü, inanç sistemi, şiirde musiki ve iç ahenk, mesajın iletilme tarzı, Hz. Peygamber ve Ehli Beyt sevgisi, kültürel mozaik, birikim, coğrafi konum, bakış açısı, Arapçanın esnekliği, şairin zevk anlayışı ve dil bilgisi gibi unsurları sayabiliriz. Bazılarının iddia ettiği gibi Arapça kelimelerin Osmanlı şiirinde varlığı bir zaaf değil bilakis geniş kültür çeşitliliği içinde tekâmül etmiş olan bu edebiyatın zenginliğidir. Divan şiirinde kullanılan Arapça kelimelerin çoğunun günümüz modern Türk şiirinde de kullanıldığını görürüz. Bu kelimelerin Türkçe olmadıklarını ve hatta ayıklanması gerektiğini ifade etmek, itinalı ve yüksek bir zevkle örülen bin yıllık kültür birikimin katli olsa gerek. Bu kelimeler Türkçenin ruhuyla izdivaç ederek toplumun ekseriyetine nüfuz etmiş dilin asli unsurlarındandır.

\section{KAYNAKÇA}

Ak, M. (2009). Türk İslam Edebiyatında Aşere-i Mübeşşere. Yayımlanmamış Yüksek Lisans Tezi, Konya: Selçuk Üniversitesi Sosyal Bilimler Enstitüsü.

Aydın, A. (2013). Ahmed Cahidi ve Divanı. Akademik Bakış Dergisi. S.36, s.1-21.

Aksu, A. (2009). Mevlana'nın Mesnevisi'nde Dört Halife. C.Ü. İlahiyat Fakültesi Dergisi, 13 (1), s.19-41.

Batislam, H. D. (2003). Divan şiirinde Âşık, Sevgili, Rakip Üçlüsü ve Ölüm. Türkoloji Dergisi, C. 9, S.34, s.186-189. Yayınlar1.

Çavuşoğlu, M. (1983). Yahya Bey ve Divanından Örnekler. İstanbul: Kültür Bakanlığı

Demirayak K. (2014). Arap Edebiyatı Tarihi I - Cahiliye Dönemi. Konya: Fenomen Yayınları.

Develioğlu, F. (2010). Osmanlıca-Türkçe Ansiklopedik Lügat. Ankara: Aydın Kitabevi.

Doğan, A. (2013). Aruz Bilgisi. Ankara: Akçă̆ Yayınları. 
Efendî, Alî Emîrî, Levâmi'el-Hamîdîye, Toronto Üniversitesi Kütüphanesi-Nüshası: PL 248/E44L4 (Orijinal, el yazması nüsha).

Erkal, A. (2009). Divan şiirinde Şebistan-ı Hayal Tarzı Üzerine. Türkiyat Araştırmaları Enstitüsü Dergisi. S. 41, s.35-45.

Gölpınarlı, A. (2006). Fuzûlî Divânı. İstanbul: İnkılap Kitabevi.

Gözütok, A. (2000). Divan şiirinin Dil Yönünden Bazı Özellikleri. Türkiyat Araştırmaları

Enstitüsü Dergisi, S.14, s.1-3.

Işınsu İ. T. (2002). Divan şiirinde Fahriye. Yüksek Lisans Tezi, Ankara: Türk Edebiyatı Bölümü, Bilkent Üniversitesi.

İz, F. (2016). Eski Türk Edebiyatında Nazım. Ankara: Akçağ Yayınları.

Kanar, M. 2015). Farsça-Türkçe Sözlük. İstanbul: Say Yayınları. Yayınları.

Kaplan, M. (1999). Şiir Tahlilleri, “Tanzimat'tan Cumhuriyete”. İstanbul: Dergâh

Kaplan, M. (2006). Kültür ve Dil. İstanbul: Dergâh Yayınları.

Kemikli, B. (2015). Türk İslam Edebiyatı. Bursa: Emin Yayınları.

Korkmaz, R. (2009). Yeni Türk Edebiyatı. Ankara: Grafiker Yayınları.

Kurnaz, C. (2012). Hayali Bey Divanının Tahlili. İstanbul: Kurgan Edebiyat Yayınları.

Kurt, A. (2015). Türk Edebiyatında Çehar Yâr-i Güzin Abdi’nin Fezail-i Hülefa-i Raşidin ve Hasail-i Çehar Yar-i Güzin Adlı Mesnevisi Üzerine Bir İnceleme. Eskişehir Osmangazi Üniversitesi Illahiyat Fakültesi Dergisi. S. 3, s.107-126.

Levend, A. S. (2015a). Türk Edebiyatı Tarihi. İstanbul: Dergah Yayınları.

Levend, A. S. (2015b). Divan Edebiyatı. İstanbul: Dergâh Yayınları.

Macit, M. - Ömür, C. - Ozan, Y. (2015). Osmanlı Nazmı. İstanbul: Kesit Yayınları.

Mengi, M. (2010). Eski Türk Edebiyatı Tarihi. İstanbul: Akçağ Yayınları.

Mermer, A. (2009). Eski Türk Edebiyatına Giriş. Ankara: Akçağ Yayınları.

Özmen, A. (2015). Nâbî’nin Siyer-i Veysî'ye Yazdĭ̆g Zeyiller. Yayımlanmamış Doktora Tezi, Diyarbakır: Dicle Üniversitesi Sosyal Bilimler Enstitüsü, Türk Dili ve Edebiyatı Anabilim Dalı.

Pala, İ. (2011). Ansiklopedik Divan şiiri Sözlüğü. İstanbul: Kap1 Yayınları.

Solmaz, S. (2004). Divan şiirinde Kelime Seçimini Etkileyen Faktörler. Türkiye Araştırmaları Dergisi. S.15, s.39-51.

Solmaz, S. (2005). Divan şiirinde Sefer, Türkiye Araştırmaları Dergisi. S.17, s.133-145. Yayınları.

Şenödeyici, Ö. (Ed.). (2015). Osmanlı Edebî Metinleri Anlama Kılavuzu. İstanbul: Kesit

Tanyıldız, A. (2013). Tuhfe-yi Lutfi. İstanbul: Akademik Kitaplar Yayınları.

Tanyıldız, A. (2016). Fuzûlî'nin Hadîkatu's-su'adâsı Üzerine Notlar. Hikmet- Akademik Edebiyat Dergisi, Prof Abdulkerim Abdulkadiroğlu Özel Sayısı, S.3, s.139-155.

Tarlan, A. N. (1981). Edebiyat Meseleleri. İstanbul: Ötüken Neşriyat. 
Tarlan, A. N. (1992). Necatî Beg Divanı. Türk Klasikleri. Ankara: Akçağ Yayınları.

Yıldırım, K. (2013). Klasik Arap, Fars, Türk ve Kürt Şiirinde Mülemma. Mülemma Dergisi. C. 1, s. 6-11.

Yüksel, F. (2010). Mihaloğlu Ali Bey Gazavat-namesindeki Klssa ve Telmihler Üzerine Bir

Inceleme”. Yayımlanmamış Yüksek Lisans Tezi, Konya: Selçuk Üniversitesi Sosyal Bilimler Enstitüsü. 
EK

\section{Divan Edebiyatı Şiirinde Sıkça Kullanılan Bazı Arapça Kelimeler ${ }^{8}$}

(A)

Abes: Kötü, yanlış davranış

Abd: Köle

Ayş: Neşeli olma hâli, yaşamak

Aduv: Düşman

Adil: Adaletli

Âlem: İnsanlar, dünya

Âlim: Bilgili uyanık

Ayan: Açık, meydanda

Ahar: Diğer

Ahir: Son

Ahfad: Oğullar

Andalip: Bülbül (kuş türü)

Acem: Arap olmayan, İranlı

Âli: Önemli, yüksek

Ahkâm: Hükümler

Azade: Hür, serbest

Azad: Hür

Azim: Yüce, büyük

Azimet: Dayanma gücü

Ataullah: Allah vergisi

Aşk: Delicesine sevgi

Avdet: Deri dönüş

(B)

Bahr-1 safa: Safa denizi: (Farsça üslubuyla terkip edilerek kullanılmış)

Baki: Beka, devamlı

Bihablil veriyd: Şah damar

Baht: Talih, kader, kısmet

Bahr: Deniz

Beyt'ül atik: Eski ev, Kâbe

Bi-vefa: Vefasız (Farsça olumsuz ekiyle

kullanılmış)

Bela: Dert, sıkıntı

Beşer: İnsan

Batın: İç, öz

Bahr: Deniz

Bülbülü ra'na: Bülbül sesli (Farsça bir

kelimeyle terkip şeklinde kullanılmış)

Bürhan: Yol, işaret

(C)

Cemal: Güzellik

Cevval: Koşan, dolaşan, hareketli

Cife: Leș, pislik

Cenk u cidal: Savaş, kavga(Farsça bir terkip

${ }^{8}$ Not: Belirtilmiş olan kelimelerin bir kısmı tek başına kullanılmışken; diğer bir kısmı da Farsça terkipler şeklinde kullanılmıştır. Tek başlarına kullanılan kelimelerin çoğu asıl manalarını korumuștur. Ayrıca belirtilmiş olan kelimeler, Divan şiirinde yer bulmuş Arapça kelimelerin sadece küçük bir kısmıdır. içinde kullanılmış)

Cari: Cereyan eden, hareketli

(D)

Darü'l karar: Karar yeri

Daim: Kalıc1, sürekli

Dar-u ukba: Baki âlem, ahiret

Defteri uşşak: Âşıkların defteri (Farsça bir terkip içinde kullanılmış)

Deha-i kutsi: Dini deha, dinde aşırı bilgili

Derk: Bir şeyin esasını anlamak

Dû âlem: İki âlem (Farsça bir terkip içinde kullanılmış.

(E)

Etfal: Çocuk

Enver: Çok parlak çok nurlu

Ezhar: Çiçekler

Ensar: Yardım eden, Medine halkı

Erihna: Bizi rahattır

Erina: Bize göster

Ezvak: Zevkler

Esir: Esir olan (Herhangi bir şeye aşırı

tutkun veya savaşta yakalanmış kişi)

Eflak: Gökyüzü, gezegenler

Enhar-1 aşk: Aşk nehri (Farsça bir üslupla kullanılmış)

Eyyam: Günler, zaman

Esma: İsimler

Ebhar: Denizler

Ebna-i Âdem: İnsanlar

Envar: Aydınlıklar

Enhar: Nehirler

Elvan: Renkler

Enzar: Bakışlar

Erbab: İnsanlar

(F)

Feta: Çocuk

Ferd: Yalnız, kişi

Fani: Ölümlü

Fahri âlem: Âlemin iftihar ettiği. Hz.

Muhammed (s.a.v)

Firkat: Dostlardan ayrılmak

Firak: Ayrılık, ayrılma

Felekler: Gökyüzü, gezegenler

Fakr u fahr: Fakirlikle iftihar etmek

Fariğ: Vazgeçmiş, çekilmiş, boş

(G/G)

Ganem (Ğanem): Koyun

Gurap(Ğuraba): Karga

Gufran (Ğufran): Affetme, merhamet etmek

Gül-i sahra: Çöl gülü (Farsça bir terkiple

kullanılmış)

Gaflet: Yolunu şaşırmak 
Ğani: Zengin

(H)

Hayye ale'l-felah: Haydi kurtuluşa

Haşru neşir: Mahşer günü

Hak: Allah

Hakir: Kötü olan, günahkâr

Hicap: Örtü, utanmak

(I/I)

Itır: Koku

Ikra: Oku

İbadullah: Allah'1n kulları

İdrak: Anlayış

İkbal: Gelecek

İnkisar: Kırılma

I'naf: sertlik göstermek

I'anet: Yardımcı, yardım etmek

İcmal: Kisaltma, özetleme

İt'am: Yedirmek, yemek

İștiyak: Özlemek

İstihal: Bir şeye layık olmak

İfşa: Açıklamak, hakikati söylemek

İstidat: Kabiliyet

İsmi pakin: Temiz isim (Farsça bir terkiple kullanılmış)

(K)

Kaf-1 kanaat: Kanaat dağı(Farsça bir terkiple kullanılmış)

Kil-ü kal: Dedi kodu

Karun: Musa (a.s.) zamanında yaşamış

zengin biri

Mu'tad: Alışmış

Muktebes: Gücünü, güzelliğini bir yerden

almak

Mübtela: Alışmış, aşırı

Mürüvet: Yiğitlik

Müstefid: Yararlanan kiși

Münevver: Nurlanmış

Münharif: Yanlış olan, yanlış yol

Müselli: Vakti hoş tutan, eğlenceli

Men reani: Beni gören

Müşkil: Sorun

Müştak: Özleyen

Mündemiç: Uyumlu

Mecellet: Kitaplar, mecmualar

Mislü: Benzer, onun gibi

Meşekkat: Zorluk/lar

Müştâki cemâlin: Cemalini özleyen

Müştak: İştiyaklı, özleyen

Men arefe nefsehu: Nefsini bilen

Miftahu'l kalb: Kalbin anahtarı

Mihrab: Yönelinen yer

Mir'at-1 zat: Kişinin aynası (Farsça terkip

üslubuyla kullanılmış)
Katre: Damla

Kenzi mahfi: Gizli hazine

Kerremna: Mükerrem kıldık

Küllü nefsin: Her nefis

Kuşe-i vahdet: Vahdet köşesi (Farsça bir terkiple kullanılmış)

(L)

Layezal: Sonsuz

Lâ mekân: Mekânı olmayan

Leylü nehar: Gece gündüz

Levlake levlak: Eğer sen olmasaydın

Lenterani: Sen beni göremezsin

Libas: Elbise, örtü

(M)

Mahbub: Sevilen

Maşuk: Âşık olunan, sevilen

Mahles: Bir kimsenin ikinci adı

Makber: Kabir

Mevla: Efendi

Memalik: Topraklar, vatan

Mazharı gufran: Affedilme, merhamete nail

olma (Farsça üslupla kullanılmış)

Mutabık: Uygun olmak

Mutadil: Orta

Muallak: Bağlı olan, asılı

Mekân: Yer

Melezzet: Lezzetli

Mureccah: Tercik edilen

Muhammer: Mayalanmış

Muin: Yardımc1

Musibet: Büyük bela

(N)

Nakatullah: Allah'ın devesi

Nefha: Güzel koku

Necip: Soyu temiz, asil

Nedamet: Tezyid

Nüzhe: Eğlence

Nikap: Peçe yüz örtüsü

Nur-u veçhinden: Yüzünün nurundan

(Farsça terkip üslubu ve Türkçe eklerle)

(R)

Rakip: Düşman

Rahmi: Rahmete mensup, rahmetle

Raih: Giden, yolcu

Raiha: Koku

Rif'at: Yükseklik, yücelik

Rücu: Geri dönmek

Rücu-u illallah: Allah'a dönmek

(S/Ş)

Sala: Minarelerde okunan salâvat 
Safa: Saflık, berraklık

Saki: Su veren, su dağıtan

Sahra: Çöl

Sahih: Gerçek olan

Sadık: Gerçek dost, doğru söyleyen

Sehâ: El açıklığı, cömertlik

Sübhan: Allah

Seher: Tan yeri ağarmadan biraz evvelki vakit, sabah namazı vakti

Sukut: Düşmek

Sükût: Susmak

Subha: Seher vakti

Sibğatullah: Allah'ın boyası

Subh: Sabah vakti

Sayf: Yaz

Sirkat: Çalıntı

Şita: Kış

Sefer: Yolculuk

Şems: Güneş

Şu'le: Alev, ateş

Şems-i aşk: Aşk güneşi

Şems-i hakikat: Hakikat güneşi

Şem': Mum

\section{(T)}

Tarik: Yol, yöntem

Tarikat: Sistem, grup

Taam: Yemek

Tafsil: Ayrıntılı

Taht-1 dil: Gönül yeri, kalp

Tahmis: Atește kızdırma, kavurma

Teselli: İyi vakit geçirmek

Teshil: Kolaylaştırmak

Tezyid: Arttırmak

Tuhfe: Hediye
Tercüman-1 aşk: Aşk tercümanı

Teğafül: Gaflet

Teğazzul: Sevgiliye güzel sözler söylemek

Tefahur: Övünç, övünme, iftihar

Tekevvün: Varolmak

Töhmet: Suç

Tı̆̆-i tevhid: Tevhid kılıcı ( Farsça terkip içinde kullanılmış)

(U)

Ulvi: Yüksek olan, kıymetli

Ulü'l-bab: Anlayışlı insanlar

Umur: İşler

Ufk/Ufuk: Geniş fikir, uzak, derin

\section{(V)}

Vasıl: Ulaşan

Visal: Ulaşma, buluşma

Venefahtü: Ona ruhumdan üfledim

Vefa: Güzeli unutmayan

Vefi: Sadık olan

Vezaret: Bakanlık

Vuzu': Abdest

Vuslat: Buluşmak

(Z)

Zaikü'l mevt: Ölümü tadacak olan

Zahir: Görünen

Zahid: Sofu, sürekli ibadet eden

81

Zahire: Ekmek, su

Zerrat: Zerreler

Zeval: Sona ermek

Zevk: Hoşnutluk

Ziyan: Zarar 